DOI: $10.17951 / 1 r p .2017 .36 .1 .235$

MaŁgorzata ChojaK

Uniwersytet Marii Curie-Skłodowskiej w Lublinie

IWONA GrochowsKa, Karolina Jurzysta, Monika MeŁgieś, Agata Karpińska

Członkinie Koła Naukowego Pedagogów i Animatorów Zabawy

\title{
ZABAWA JAKO WARUNEK PRAWIDŁOWEGO ROZWOJU DZIECI I PRZYGOTOWANIA STUDENTÓW DO ZAWODU NAUCZYCIELA - PRZYKŁAD DOBREJ PRAKTYKI
}

\begin{abstract}
Abstrakt: Powszechnie wiadomo, że zabawa ma ogromny wpływ na rozwój małego człowieka, ponieważ już od najmłodszych lat towarzyszy mu na ścieżce rozwoju jako narzędzie przejawiania aktywność. Jest to nie tylko sposób na poznanie świata i siebie samego, ale również metoda uczenia się nowych umiejętności, wyrażania emocji, reagowania na trudne wydarzenia czy po prostu - relaks. Jak ważna jest dla dziecka zabawa, podkreślają liczne wyniki badań wskazujące na zaburzenia rozwojowe dzieci, które nie miały jej wystarczająco dużo. Istotny jest również fakt, że zabawa to często najbardziej efektywny sposób komunikacji między dzieckiem a osobą dorosłą. Dlatego powinna być częścią każdych studiów przygotowujących nauczycieli do pracy zawodowej z dziećmi.
\end{abstract}

Słowa kluczowe: dziecko, zabawa, rozwój

\section{Z TEORII ZABAWY}

Papież Jan Paweł II na jednym ze spotkań z małymi pacjentami w Instytucie Pediatrii Akademii Medycznej powiedział: „zabawa jest nie tylko przejawem potrzeby rozrywki czy dowodem lekkomyślności, lecz - nawet wtedy gdy nie zdajecie sobie z tego sprawy - jest okazją do kształtowania charakteru i pielęgnowania cnót" (za: Minczakiewicz 2013, s. 18). Każde dziecko, niezależnie od osiągniętego poziomu 
rozwoju fizycznego i intelektualnego, ma wrodzoną potrzebę bawienia się. Dlatego dotychczas powstało wiele publikacji naukowych i popularnonaukowych dotykających tej kwestii. Można nawet powiedzieć, że temat został już wszechstronnie omówiony i nie warto ponownie go poruszać. Jednak zmiany społeczne, jakie zachodzą w rodzinach (zmiana roli kobiety, zmniejszenie dzietności rodziny, zwiększenie liczby rozwodów) oraz bardzo szybka cyfryzacja rzutują nie tylko na jakość i formę zabawy, lecz także na dewaluowanie, pomijanie, zapominanie jej znaczenia. Rodzice szukają dziś dla dziecka dobrego przedszkola czy prestiżowej szkoły. Jednakże wśród kryteriów wyboru próżno szukać tych związanych z radością malucha czy motywacją do podejmowania zabaw lub manipulacji otoczeniem. Dorośli (często zapracowani) zapominają o ogromnej roli zabawy w życiu dziecka albo zmieniają jej znaczenie na tzw. własne potrzeby - podobnie jak Platon, który w zabawie nie widział nic pożytecznego.

Tymczasem badania Stuarta Browna wskazują, że brak czasu na swobodną zabawę w dzieciństwie niesie poważne konsekwencje dla jakości życia w dorosłości. Przeprowadzając wywiady z zabójcami, odkrył, iż większość z nich miała dwie wspólne cechy: w przeszłości spotkali się z przemocą w rodzinie i nigdy się nie bawili. Inne doniesienia sugerują, iż właśnie zabawa jest kluczowa dla prawidłowego społecznego rozwoju dziecka. Ponadto uważa się, że pomaga ona w radzeniu sobie z lękiem. Badania przeprowadzone w Michigan w 1997 roku pokazały, że co trzecie z dzieci, których zachowanie w przedszkolu było stale pod ścisłą kontrola dorosłych, popełniło później przestępstwo i zostało aresztowane przed ukończeniem 23. roku życia. Dla porównania - wśród dzieci z przedszkoli nastawionych na zabawę ten odsetek nie sięgał 10\%. Podobne różnice zanotowano w statystykach dotyczących kariery zawodowej: podopieczni przedszkoli praktykujących głównie nauczanie, a nie zabawę, ponad trzykrotnie częściej tracili pracę niż ich rówieśnicy, którzy mogli swobodnie bawić się w dzieciństwie (Wenner 2009).

Nasuwa się zatem pytanie: „Czym jest zabawa, co jest jej celem, co odróżnia ją od pracy czy nauki?".

Przez lata wypracowano wiele definicji. Słowo zabawa wywodzi się od łacińskiego ludus i oznacza beztroską, swobodną aktywność ruchową oraz figlowanie. $\mathrm{W}$ języku polskim definicja ta ma swoje korzenie w zwrocie zabawiać się, rozumianym początkowo jako zajmowanie się czymś, trudzenie się (Maciejewska-Mroczek 2012, s. 91). Dopiero z czasem pojęcie, które wcześniej oznaczało zatrudnienie, a nawet przeszkodę, otrzymało pozytywne zabarwienie, kojarzące się z odczuciem przyjemności i mile spędzonego czasu. Takie spojrzenie na zabawę znajdziemy w definicji Łukasza Gołębiowskiego, który twierdzi, że prawo do zabawy przysługuje każdemu, bez względu na wiek i zajmowaną pozycję: 
zabawa jest celem gry najprostszej, najlichszej i najwyszukańszej, tysiąc kombinacji za sobą pociągającej. Szuka ją zarówno wiek dziecinny, średni i podeszły, nie odrzuca późna starość nawet; po trudach i pracy rozrywa się nią w swobodniejszej chwili kmiotek, mieszczanin, kupiec, szlachcic, pan możny, za nią się ubiega rycerz i prawnik, człowiek światowy i kapłan lub zakonnik, uczony i prostak, płeć jedna i druga, z tą tylko różnicą, że sobie właściwie szuka, tę wybiera, tej nad innemi daje pierwszeństwo; a stąd wielka jest rozmaitość, niezliczona prawie mnogość, i trudne ich liczenie, podział, opisanie trudne (za: Maciejewska-Mroczek 2012, s. 90).

Współcześnie zabawę przeważnie kojarzy się z czynnością podejmowaną wyłącznie dla przyjemności (Okoń 1987, s. 934; Hurlock 1985, s. 365; Huizing 1985, s. 22). Anna Brzezińska pisze wprost:

zabawa jest jedną z podstawowych form aktywności człowieka w każdym wieku. Pojawia się w różnych fazach rozwoju i pełni różną w nich rolę. Przyczyniając się do rozwoju, sama także temu rozwojowi podlega. Jednak najpełniej rozwija się w okresie dzieciństwa i dlatego jest uważana za taki rodzaj aktywności, bez którego rozwój dziecka po prostu nie może przebiegać prawidłowo. Prawdziwa zabawa, czyli stworzona przez dziecko od początku do końca, występuje głównie w wieku przedszkolnym, który nazywany bywa czasem po prostu wiekiem zabawy (Brzezińska 2011).

Należy więc pamiętać, że zabawa, to czynność spontaniczna, bezinteresowna i bezproduktywna. W jej trakcie dziecko może przebywać w innym czasie i miejscu, może przeżywać wiele silnych, czasem skrajnym emocji, ale jednocześnie wyraźne dąży do przestrzegania reguł i skupienia się wyłącznie na zabawie. Musi ona zatem być przede wszystkim dobrowolna. W momencie gdy się nas do niej zmusza, traci swój sens. Zabawa jest dobra, kiedy jest atrakcyjna, wzbudza zainteresowanie, przykuwa uwagę i dostarcza radości (Czub 1995, Erikson 1995, Winnicott 1995).

Dlaczego jednak dzieci ją podejmują; dlaczego u każdego malucha istnieje tak silna potrzeba zabawy?

Odpowiedzi na to pytanie poszukiwano przez lata. Teoria nadmiaru energii, której wyznawcami byli Herbert Spencer i Fryderyk Schiller, rozpowszechniła pogląd, iż dzieci bawią się po to, aby pozbyć się nadwyżki niewyczerpanej energii, a ich zabawa polega przede wszystkim na naśladowaniu dorosłych. Myśl ta spotkała się z falą krytyki, dlatego też zaczęto szukać innych teorii przedstawiających istotę zabawy. Na przełomie XIX i XX wieku popularne stało się stanowisko reprezentowane m.in. przez Stuarta Halla, który porównywał rozwój zabawy dzieci do 
historycznego rozwoju ludzkości, tłumacząc tym samym sens zabaw w polowanie, podchody, gonitwy itd. I tym razem nie zabrakło krytyków, którzy podważyli owe tezy, gdyż uznali je za powierzchowne. Kolejną próbą wyjaśnienia genezy zabawy była teoria ćwiczenia przygotowawczego stworzona przez Karola Grossa. Jej główną myśl stanowi rozumienie zabawy jako szkoły przygotowującej do przyszłego życia. Mimo że stanowisko to wywarło duży wpływ na psychologię dziecka, krytykuje się je za jednostronność - poruszanie wyłącznie biologicznej strony tematu. Odmienne podejście prezentowałÉdouard Claparède akcentujący dwa aspekty zabawy i doszukujący się w niej zarówno przygotowania do późniejszych aktywności, jak i funkcji zastępczej - uczenia wykonywania czynności „na niby” (Okoń 1987, s. 49-63). Chociaż zaprezentowane teorie różnią się od siebie, zwracają uwagę na inne aspekty zabawy (biologiczny, społeczny, kulturowy), to każda z nich jest ważna w definiowaniu omawianego pojęcia i dopiero połączenie tych podejść daje pełny obraz zabawy i możliwość zrozumienia jej genezy. Najbardziej istotny jest fakt, że dziecko samoistnie potrzebuje zabawy do funkcjonowania.

\section{Czy jednak każdej zabawy? Czy są zabawy mniej i bardziej potrzebne?}

$\mathrm{W}$ pedagogice i psychologii istnieje wiele różnych podziałów zabaw dla dzieci. Zgodnie z najpopularniejszym, stosowanym w przedszkolu, wyróżnić można:

- zabawy dydaktyczne kształcące umiejętności intelektualne i służące utrwalaniu zdobytej wiedzy i umiejętności przyrodniczych, matematycznych, społecznych, językowych (poszerzają słownictwo dziecięce)';

- zabawy konstrukcyjne (klockami, plasteliną, tworzywem przyrodniczym, masą solną itp.);

- zabawy manipulacyjne polegające na zmienianiu różnych przedmiotów, na ich składaniu i rozkładaniu, mające na celu wspieranie przede wszystkim rozwoju motorycznego, ale także koncentracji i umiejętności planowania;

- zabawy tematyczne (inaczej: fikcyjne, naśladowcze, twórcze, „w role”), w których dziecko przyjmuje samodzielnie role związane z życiem domowym, przedszkolnym, zaczerpnięte np. $z$ ulubionej literatury dziecięcej. Przedmioty, zabawki w tych zabawach przyjmują często symboliczne nazwy ${ }^{2}$;

- zabawy ruchowe kształtujące prawidłową postawę, służące wyrabianiu cech motoryki, takich jak: siła, zręczność, zwinność, wytrzymałość. Wpływają na rozwijanie umiejętności współdziałania w grupie, w zespole,

\footnotetext{
1 Są to zabawy proponowane przez dorosłych w celu rozwiązania poleconych zadań. Zaliczyć można do nich historyjki obrazkowe, loteryjki, łamigłówki i gry edukacyjne, zagadki, rebusy.

2 Zabawy te wynikają z twórczej inicjatywy dzieci, a rola nauczyciela polega tylko na obserwacji zachowań służącej diagnozowaniu umiejętności społecznych dzieci.
} 
w parze. Uczą zdrowej rywalizacji i dyscypliny, służą zarówno relaksowi, jak i hartowaniu organizmu³.

Maria Kwiatkowska przyjmuje następujący podział zabaw:

- samorzutne zabawy dzieci;

- zabawy organizowane przez nauczycieli (dorosłych).

Do zabaw samorzutnych zalicza się zabawy: tematyczne, konstrukcyjne, ruchowe, badawcze, natomiast do zabaw organizowanych przez nauczyciela: zabawy i gry dydaktyczne, zabawy ruchowe i zabawy inscenizowane. Poszczególne typy odgrywają w rozwoju dziecka swoje role, dlatego każdy z nich powinien mieć możliwość występowania. Inny podział zabaw według Kwiatkowskiej, dokonany ze względu na inicjatywę i samodzielność dziecka, obejmuje: zabawy spontaniczne, spontaniczne z udziałem nauczycielki oraz zabawy według ściśle określonych zasad. Podobnie jak Kwiatkowska podział zabaw przyjęty w przedszkolach przedstawia Stanisława Lipina, dzieląc je na dwie grupy: zabawy dowolnie podejmowane i organizowane przez same dzieci oraz zabawy inicjowane przez nauczycieli. Pierwsza grupa to zabawy manipulacyjne, konstrukcyjne, ruchowe, twórcze określone jako tematyczne, naśladowcze, inscenizowane. Do drugiej grupy należą zabawy dydaktyczne i ruchowe z prawidłami. „W zabawach pierwszej grupy, szczególnie twórczych, aktualizuje się całe bogactwo zdobytych przez dziecko wyobrażeń, które polegają na "wprowadzeniu« na niby w czyn tego, co dziecko już wie o niedostępnym świecie, w jakim żyją i działają dorośli” (Lipina 1981, s. 19-20).

Niezależnie od formy zabawy pełnią konkretne funkcje, które Elizabeth Hurlock podzieliła, przyjmując za kryterium typ zmian, jakie pod wpływem zabawy dokonują się u dziecka. Są to:

- funkcja kształcąca (rozwijającą zmysły, sprawność motoryczną, wzbogacają wiedzę o świecie);

- funkcja wychowawcza (ucząca przestrzegania norm, reguł i umów związanych z postępowaniem);

- funkcja terapeutyczna, inaczej korekcyjna (pozwalająca uwolnić się od negatywnych uczuć, napięć, a jednocześnie poznać różne sposoby wyrażania emocji);

- funkcja projekcyjna (umożliwiająca dziecku „pośrednie” wyrażenie problemów, trudności, jak również zainteresowań, możliwości, słabych i mocnych stron związanych z rozwojem; dla dorosłego jest to szansa na lepsze poznanie i zrozumienie poszczególnych zachowań dziecka) (Hurlock 1987, s. 367).

3 W tych zabawach, organizowanych w sali i na powietrzu, wykorzystywane są różne przybory gimnastyczne i przyrządy ogrodowe. Można w nich zauważyć cechy ruchu twórczego, ścisłego, odtwórczego, zabawowo-naśladowczego. 
Z kolei Wincenty Okoń (1987) określił funkcje zabawy następująco: zabawauczenie się, zabawa-praca, zabawa-aktywność społeczna. Na tej podstawie można sądzić, że zabawa jest zarówno pracą, jak i nauką, ale podejmowaną dobrowolnie i sprawiającą dziecku przyjemność.

Warto pójść o krok dalej i spojrzeć na zabawę jako na czynnik kształtujący osobowość małego człowieka, czego podjął się w swojej teorii psychologicznej George Mead (Maciejewska-Mroczek, s. 97). Stwierdził on, że osobowość rozwija się wyłącznie w relacji z innymi osobowościami, a gry są ku temu najlepszą okazją. Dziecko przejmuje wtedy czyjeś role, musi się z nimi zapoznać i je zrozumieć. Nie sposób zatem nie docenić faktu, iż zabawa jest doskonałym treningiem emocjonalnym i społecznym (Ożadowicz, Rękosiewicz 2011). Kiedy dzieci bawią się ze sobą (nie obok siebie), mają możliwość nawiązywania kontaktów oraz współdziałania werbalnego i rzeczowego. Początkowo owe kontakty są nietrwałe i dosyć przypadkowe, co zmienia się wraz z wiekiem dzieci. Dążenie do nawiązywania kontaktu społecznego objawia się najsilniej między piątym a dziesiątym rokiem życia. Dzieci uczą się od siebie pewnych zachowań, korygują niepoprawne - ich zdaniem - działania, pouczają siebie nawzajem, odgrywają określone role, kierując się przy tym intuicyjnie przyjętymi normami dorosłych. Szczególną szansę na uświadomienia sobie i przyswojenie zasad postępowania dorosłych dają zabawy tematyczne. Po bacznej obserwacji przedstawicieli różnych zawodów wchodzą w rolę lekarza, krawcowej, mechanika itd., wykorzystując do tego akcesoria związane z daną branżą. Wybór tematu zabawy nie jest przypadkowy, wiąże się z najbliższym otoczeniem bądź doświadczeniami (Truskolaska 2007). Wraz z wiekiem dziecka zabawy te stają się coraz bardziej osadzone w rzeczywistości, i tak w odtwarzaniu danej sytuacji przez pięcio-, sześcio- czy siedmiolatki doszukać się można dużego realizmu, co daje dzieciom możliwość oceny czy dany zawód działa dobrze, czy źle. Kształtują tym samym własny system wartości. Ponadto poznawanie sytuacji społecznych i ćwiczenie uczestnictwa w nich pomaga wypracować zachowania, które są akceptowane (Czub 2013). Dzieci w wieku przedszkolnym zaczynają rozpoznawać, jakie działania spotykają się z aprobatą dorosłych, a dzieci przekraczające próg szkoły - a więc będące w wieku wczesnoszkolnym - utrwalają te spostrzeżenia. Do umiejętności nabytych podczas przebywania $z$ drugim człowiekiem zaliczamy: powstrzymywanie chęci natychmiastowego zaspokojenia potrzeby, co wiąże się np. z czekaniem na swoją kolej podczas gry, przestrzeganie reguł ustalonych przez innych, eliminowanie agresji fizycznej, rozwiązywanie problemów, zwracanie się o pomoc. Ponadto zabawa uczy malucha pokonywania trudów życia poprzez kształtowanie takich cech charakteru, jak: cierpliwość, wytrwałość, tolerancja, uczciwość, rzetelność i pracowitość. Patrząc na płaszczyznę społeczną, można pokusić się o stwierdzenie, że zabawa jest treningiem przygotowującym do pełnienia ról w dorosłym życiu, 
upiększa je i daje możliwość nawiązywania związków duchowych i społecznych istotnych zarówno dla jednostki, jak i dla grupy.

Mówiąc o aspekcie społecznym, nie sposób ominąć aspektu emocjonalnego. Nie chodzi tu jedynie o wywoływanie pozytywnych emocji i przyjemnych doznań u dziecka, ale także o uwolnienie go od przykrych uczuć. W ten sposób nadajemy zabawie funkcję katartyczną. Aby ją prawidłowo zrozumieć, należy wyjaśnić słowo katharsis. Jest to termin pochodzący od łacińskiego kathaireo, co znaczy pokonywać, przezwyciężać. Termin ten, początkowo używany w sztuce teatralnej, został przeniesiony na grunt pedagogiki, w której odnosi się do oczyszczania duszy dziecka z pewnych aspołecznych skłonności poprzez zabawę (Okoń 1987, s. 71). Istotą funkcji katartycznej jest fakt, że to dziecko kontroluje emocje - nie pozwala, by przejęły one władzę. Rozładowywanie napięcia emocjonalnego zachodzi szczególnie podczas zabawy spontanicznej i swobodnej.

Zabawa podejmowana spontanicznie jest nie tylko treningiem emocjonalnym, ale daje również szansę na to, by dziecko doskonaliło umiejętności, zdobywało doświadczenie i testowało swoje możliwości. Nauka swobodna, nazywana autoedukacją przez zabawę, pozwala na mimowolne i niezamierzone zdobywanie wiedzy teoretycznej i praktycznej (Kaczmarska, Zamęcka 2013). Najistotniejsze wydaje się, żeby dziecko mogło eksplorować otoczenie, wszystkiego dotknąć i - o ile to możliwe - spróbować. W tym celu trzeba mu zapewnić rozmaite przedmioty różniące się ze względu na kształt, fakturę, kolor. Dziecko, kierowane niepohamowaną ciekawością, będzie podejmować inicjatywę zbadania środowiska, a czując sprawstwo, stanie się dumne z efektów swoich działań. Rozwój sfery poznawczej przyczynia się do zwiększenia poczucia kompetencji i wzrostu samooceny, ale także do przezwyciężania nieśmiałości. Swobodna aktywność dziecka pozwala na odkrycie różnych sposobów radzenia sobie z danym problemem.

Czy zatem pojmowanie nauki i zabawy jako oddzielnych aktywności jest słuszne? Z naszych rozważań jasno wynika, że poprzez zabawę dziecko zdobywa wiedzę mimo braku nastawienia na uczenie się.

Rozwój poznawczy dziecka nie byłby możliwy bez zaspokojenia potrzeby ruchu i eksploracji. Zatem niewłaściwe byłoby pominięcie rozwoju fizycznego podczas rozważania kwestii zabawy. Umożliwia ona rozładowanie nadmiaru energii poprzez różne formy aktywności. Co więcej, stanowi pozytywny czynnik w rozwoju mięśni i kośćca dziecka, zapewnia tym samym modelowanie sylwetki, której obce są wszelkie krzywizny i deformacje. Za niezaprzeczalną zaletę zabawy należy uznać wpływanie na procesy metaboliczne, co szczególnie cenne jest $\mathrm{w}$ walce $\mathrm{z}$ otyłością - chorobą cywilizacyjną XXI wieku. Tak więc aktywność fizyczna zapobiega magazynowaniu się zbędnych zapasów tłuszczu i toksyn, co daje efekt wysmuklenia sylwetki. Biorąc pod uwagę powyższe rozważania, można przypisać zabawie 
rolę życiodajnego tlenu, bez którego nie byłoby możliwe wykonywanie tak wielu czynności (Minczakiewicz 2013, s. 18).

Podsumowując, można powiedzieć, że zabawa warunkuje rozwój dziecka we wszystkich sferach: rozwija motorykę (małą i dużą), pozwala doświadczać świata i uczyć się go, wyrażać emocje, budować relacje z innymi ludźmi. Dzieje się tak niezależnie od rodzaju i formy zabawy. Różne jest jedynie nasilenie jej funkcji. Dlatego jeśli osoba dorosła planuje uzyskanie konkretnego efektu, powinna świadomie dobierać rodzaj zabawy (tj. stwarzać do niego warunki, inicjować go).

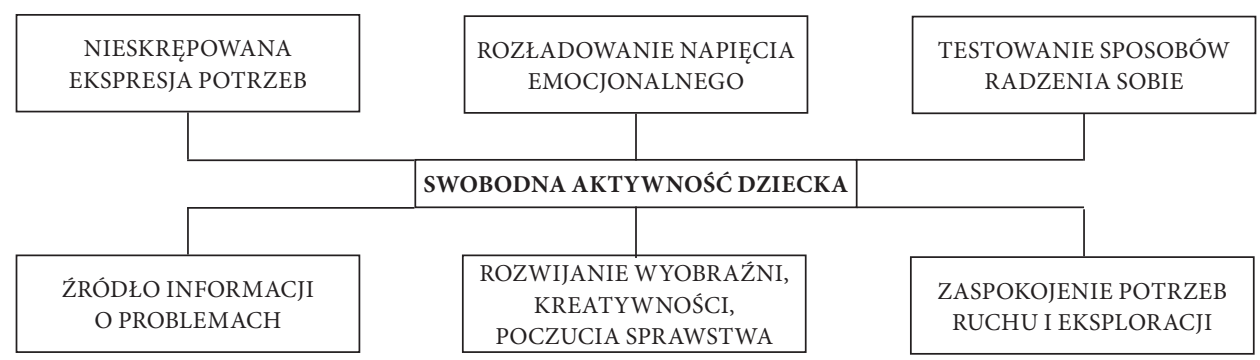

Rysunek 1. Zabawa jako swobodna aktywność dziecka

Źródło: Kaczmarska, Zamęcka 2013, s. 46.

Zabawa jest konieczna zwłaszcza u dzieci w wieku przedszkolnym i wczesnoszkolnym. Dla najmłodszych stanowi podstawową formę aktywności, dlatego okres przedszkolny często nazywa się „wiekiem zabawy”. Jaka rolę pełni w nim jednak dorosły?

Czujny nauczyciel, opiekun czy rodzic na podstawie obserwacji bawiącego się dziecka jest w stanie zdiagnozować jego potrzeby, zauważyć, czego mu brakuje, jakie ma możliwości, rozpoznać jak funkcjonuje w środowisku. Co ciekawe, ku zdziwieniu rodziców zdarza się, że dziecko w zabawie używa niecodziennego, nadzwyczajnego, wręcz wyszukanego słownictwa, moduluje ton głosu, a nawet wykonuje czynności z niespodziewaną precyzją (Kaczmarska, Zamęcka 2013, s. 44). Możliwe jest zatem dostrzeżenie strefy najbliższego rozwoju, co oznacza, że czujny opiekun zwróci uwagę na to, jakie są predyspozycje dziecka. Zauważając je, będzie mógł proponować zabawy w taki sposób, aby wykorzystywały one potencjał malucha. Na przykład sposobem inicjowania zabawy, która pozwoli na rozwinięcie rodzących się umiejętności dopasowywania do siebie rzeczy pod względem koloru i kształtu będzie zachęcenie dziecka do układania puzzli. Pozwoli to nie tylko na doskonalenie tej umiejętności, ale także zapewni rozrywkę i płynącą z niej przyjemność. Dorosły, jako obserwator zabawy swoich pociech, może doszukać się odpowiedzi na frapujące go pytanie: „W jakim stopniu moje dziecko 
jest zdolne do wykonywania prostych czynności dnia codziennego?”. Co więcej, w zabawie może odnaleźć jej jakże prozaiczny walor - to, że dziecko potrafi samo zagospodarować swój wolny czas, a tym samym pozwolić opiekunom na chwile oddechu i relaksu.

Zabawa daje zatem obopólne korzyści - przede wszystkim dla dziecka, ale też dla dorosłego, który po odkryciu możliwości podopiecznego jest w stanie ukierunkować jego dalszy rozwój. Nie można przecenić znaczenia i roli zabawy dla dziecka w wieku przedszkolnym i wczesnoszkolnym. O tym, jak bardzo jest ona wartościowa, świadczy sam fakt poruszenia tematyki z nią związanej w celach Podstawy programowej wychowania przedszkolnego (Karbowniczek, Kwaśniewska, Surma 2013, s. 296). Wynika z niej, że 1/5 czasu pobytu dziecka w przedszkolu powinna być przeznaczona na zabawę swobodną. W świetle tego faktu widoczne jest spychanie zabawy na margines, a tym samym hamowanie aktywności dziecka. Z przeprowadzonych licznych obserwacji można wysunąć pewne niepokojące wnioski. Po pierwsze, nauczyciele bardzo sztywno przestrzegają rozkładu dnia, co czyni niemożliwym rozwinięcie się i pełne ukształtowanie swobodnego działania, dochodzi nawet do jego przerywania. Po drugie, obserwowalne jest skupianie się na zajęciach dydaktycznych i na efektach działania, a nie na pobudzeniu kreatywności i pomysłowości dziecka. Jeśli chodzi o nauczanie w klasach I-III, spotkać się można z niedocenianiem roli zabawy i spychaniem jej na drugi plan, a także rozgraniczeniem jej od nauki i pracy. Zapomina się o tym, że wspierając ciekawość, aktywność, samodzielność dziecka, zapewnia się mu lepsze szanse edukacyjne. Można się nawet pokusić o stwierdzenie, że zabawa jest czymś nadzwyczajnym, a wręcz magicznym. Rzeczy i sytuacje niedostępne i niemożliwe dla dziecka stają się namacalne, a ono samo przenosi się w idealny świat marzeń, odległy od trosk, zakazów, barier, niebezpieczeństw. Zacierają się granice nie tylko między wyobraźnią a rzeczywistością, ale także między poszczególnymi dziećmi o zróżnicowanych możliwościach rozwoju, co wpływa na zanik podziałów wśród bawiących się (Lubomirska 2006, s. 6). Każdy uczestnik jest równy, zobowiązany do przestrzegania tych samych reguł gry - wszyscy mają równe szanse na doświadczanie radości i poczucia sprawstwa. Tym samym dziecko czuje się ważne w swoim środowisku, kształtuje silną pozycję wśród rówieśników i nabiera pewności siebie. Zabawa stawia je w ponadto w sytuacjach trudnych, wymagających znalezienia rozwiązania problemu czy współpracy z innymi osobami. Wspólne działania uwrażliwiają małego człowieka na zachowania altruistyczne, budują więzi międzyludzkie, uczą zgodnego współżycia, tolerancji i podporządkowania się grupie. Pierwsze próby życia zgodnego $\mathrm{z}$ zasadami i akceptowanymi granicami są niezwykle dużym wyzwaniem dla dziecka. Zjawisko to łączy się także z dążeniem przez malucha do autonomii, co $z$ kolei może być trudne dla rodzica. Mądry rodzic zrozumie jednak, że swobodna 
aktywność dziecka pobudza jego ciekawość i motywuje do eksplorowania otoczenia, a tym samym przyczynia się do autoedukacji. Ciekawość świata generuje chęć zdobywania wiedzy, nowinek. Dziecko jest bardzo ruchliwe, gdyż pragnie odkryć odpowiedzi na nurtujące go pytania. Zabawa pozwala mu zatem pozbyć się nadmiaru energii, wykorzystać ją w słusznym celu, a jednocześnie przyczynia się do rozwoju fizycznego malucha, jego zręczności, sprawności i zwinności. Zdolności te są szczególnie ważne w grach zespołowych dzieci w wieku wczesnoszkolnym, kiedy to drużyny rywalizują ze sobą, czują ducha walki i bojowe nastawienie do przeciwnika. Mimo ogromnego wysiłku fizycznego zawodnik zdaje się nie odczuwać zmęczenia, a jedynie czystą przyjemność i radość. Śmiało więc można stwierdzić, iż zabawa jest lekiem na wszystkie dziecięce smutki i troski, pozwala na chwilę zapomnienia i oderwania się od tego, co szare i przyziemne. Zatem niech poniższe słowa będą wskazówką dla każdego mądrego rodzica i nauczyciela: „Choć gra tworzy własną realność i buduje zamknięty świat, to nie można zaprzeczyć, że w tym fikcyjnym świecie uczestnicy pokazują swe zalety cenione także gdzie indziej, jak zręczność, inteligencję, samokontrolę, wiedzę" (Maciejewska-Mroczek 2013, s. 102).

Podobnie rzecz się ma w przypadku zabawy, która jest czynnikiem warunkującym rozwój dziecka. Ale i jako złożona forma działalności dziecka także podlega ona procesowi rozwoju. Zabawy dziecięce u progu okresu przedszkolnego różnią się więc znacząco od zabaw/gier pod koniec wieku szkolnego, tj. u progu okresu dorastania. Zmianie ulega nie tylko i nie tyle ich forma (to, w co i jak dziecko się bawi), ale przede wszystkim funkcje, sens, znaczenie dla rozwoju (Brzezińska, Burtowy 1992, s. 78-94). U osób dorosłych zabawa spełnia przede wszystkim funkcję relaksacyjną; nie jest wiodącą aktywnością i często uznaje się ją za niepotrzebną. Niestety, takie pojmowanie jest przekazywane lub nawet narzucane dzieciom. Dlatego tak istotne wydaje się przypomnienie wagi zabawy - zwłaszcza osobom, które przygotowują się do pracy zawodowej z najmłodszymi.

\section{Z PRAKTYKI ZABAWY}

Bardzo dobrym sposobem na praktyczne przekazanie teorii zabawy wydaje się udział studentów np. w pracach kół naukowych. Na Wydziale Pedagogiki i Psychologii UMCS działa Koło Naukowe Pedagogów i Animatorów Zabawy. Jego członkowie to w znacznej większości studenci pedagogiki o specjalności przedszkolnej i wczesnoszkolnej, a więc osoby, które będą pracować z dziećmi, dla których zabawa jest najważniejszą albo jedną z najważniejszych form aktywności, niezbędną do prawidłowego rozwoju. Jeśli nauczyciel ma efektywnie pracować, realizować założenia podstawy programowej z przedszkolakiem czy uczniem, musi nie tylko 
rozumieć, ale również stosować w praktyce różne formy zabawy. Można zaryzykować twierdzenie, że jest to tak samo ważna umiejętność, jak nauczanie pisania czy czytania. Niestety, na niewielu uczelniach studenci mają możliwość nabywania wiedzy z teorii zabawy i ćwiczenia w praktyce sposobów jej organizowania, stymulowania i rozumienia czy wykorzystywania.

Dlatego tak istotne wydaje się prezentowanie dobrych praktyk w tym zakresie. Przykładem jest działalność Koła Naukowego Pedagogów i Animatorów Zabawy UMCS, które istnieje od 2014 roku i ma na celu:

a) działalność naukowo-badawczą prowadzoną poprzez:

- organizację konferencji i uczestnictwo w nich, a także w dyskusjach i seminariach poruszających zagadnienia pedagogiki zabawy we współczesnej edukacji;

- uczestnictwo w wydziałowych projektach naukowych;

- projektowanie i prowadzenie własnych badań naukowych;

- podnoszenie kwalifikacji naukowych przez udział w szkoleniach i warsztatach dotyczących m.in. pisania artykułów naukowych i aplikowania o granty;

- współpracę z polskimi i zagranicznymi ośrodkami naukowo-badawczymi.

b) popularyzowanie idei pedagogiki zabawy przez:

- prowadzenie warsztatów, festynów itp. na prośbę placówek naukowych i oświatowych, organizacji pozarządowych i innych zainteresowanych oraz we współpracy z nimi;

- organizowanie spotkań z „praktykami pedagogiki zabawy”;

- wizytacje różnych placówek i instytucji, w których wykorzystuje się w procesie edukacji elementy „pedagogiki zabawy”.

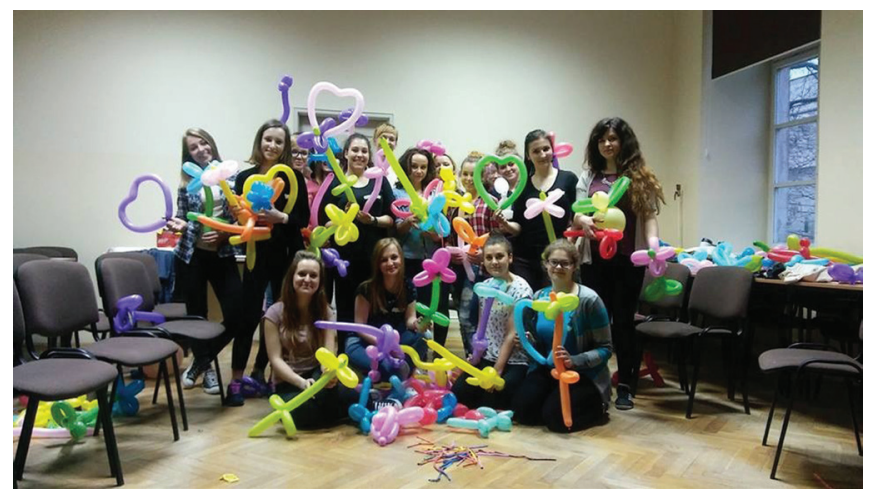

Zdjęcie 1. Szkolenie dla samorządu studenckiego zorganizowane przez członków Koła na terenie Wydziału Pedagogiki i Psychologii

Źródło: materiały własne Koła. 
Koło skupia corocznie około 40 studentów, głównie z kierunku pedagogika. Każdy z nich ma obowiązek uczestniczyć w czterech imprezach w placówkach oświatowych (jedną przygotowuje sam) oraz dodatkowych spotkaniach szkoleniowych (z zakresu pedagogiki zabawy, ruchu rozwijającego Weroniki Sherborne, Metody Dobrego Startu Marty Bogdanowicz, arteterapii itp.). W ramach współpracy z innymi wydziałami i samorządem studenckim członkowie Koła sami organizują również szkolenia dla innych osób.

W ramach pracy Koła organizowanych jest zazwyczaj około 12 imprez tematycznych i okolicznościowych dla dzieci. Uwzględnia je harmonogram układany na początku każdego roku akademickiego. Imprezy te przeznaczone są zwłaszcza dla dzieci z placówek przedszkolnych oraz ze szkół podstawowych. Można wśród nich wyróżnić:

- bale karnawałowe,

- bale andrzejkowe,

- imprezy z okazji Dnia Dziecka i mikołajek,

- pikniki rodzinne,

- imprezy okolicznościowe związane z działalnością placówki (m.in. jubileusze przedszkoli),

- inscenizacje,

- kąciki animatorów (a w nich liczne zabawy z chustą KLANZY, zabawy ruchowe i wiele innych).

Każda z przeprowadzanych imprez ma motyw przewodni, któremu podporządkowany jest cały scenariusz prowadzonych zajęć, tak by był on spójny i kompletny. W celu jeszcze lepszego wprowadzenia uczestników zabawy w daną tematykę prowadzący przygotowują liczne pomoce i rekwizyty oraz na potrzeby zabaw przebierają się np. za wróżki, motyle, kwiaty, zwierzęta i inne postacie.

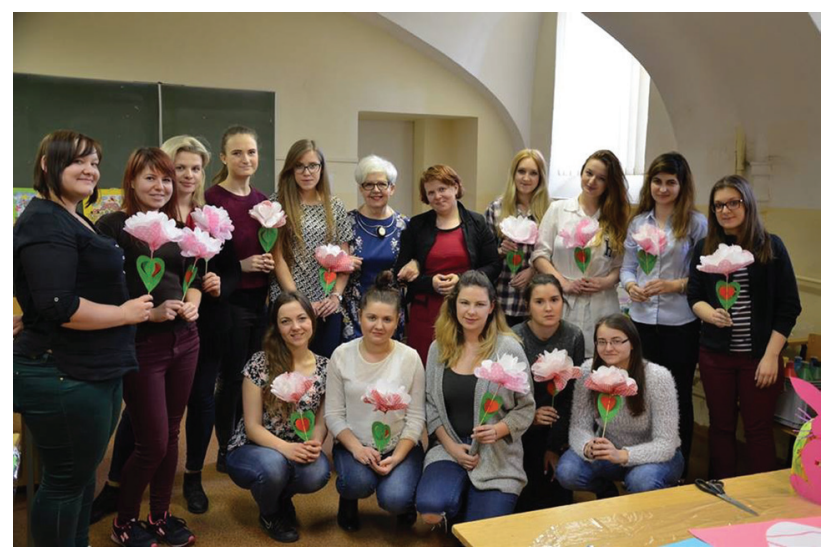




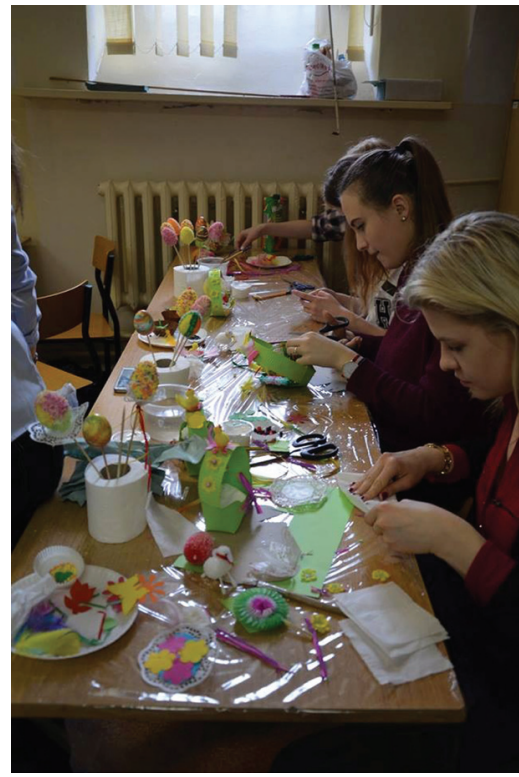

Zdjęcia 2 i 3. Szkolenie z arteterapii zorganizowane przez firmę „Animi-Artes” w ramach umowy partnerskiej o współpracy

Źródło: materiały własne Koła.

Uczelnia współpracuje z wieloma placówkami oświatowymi. Z częścią z nich ma podpisane umowy o współpracy. Na początku października przedstawiciele placówek spotykają się z koordynatorem do spraw współpracy i zgłaszają propozycje tzw. harmonogramu współpracy uwzględniającego m.in. różne działania, w których mogliby uczestniczyć studenci. Po zatwierdzeniu harmonogramu każda placówka dostaje kontakt telefoniczny do członka Koła odpowiedzialnego za koordynację tego aspektu współpracy (dyrekcja na dwa tygodnie przez imprezą dzwoni w celu potwierdzenia i umówienia pierwszego spotkania). Koordynator tworzy listę imprez i wydarzeń, do przygotowania których przypisuje po dwie osoby spośród członków Koła. Ich zadaniem jest zaplanowanie imprezy, zebranie grupy studentów, opracowanie scenariusza, przygotowanie materiałów (koszt ewentualnych zakupów pokrywa zawsze placówka), znalezienie muzyki itp. Końcowy etap każdej imprezy stanowi przygotowanie zaświadczeń dla studentów oraz promocja wydarzenia na stronach uczelni.

Studenci muszą zatem wykazać się nie tylko umiejętnościami organizacyjnymi, ale także stale pogłębiać wiedzę z zakresu teorii zabawy, by właściwie dobrać i zrealizować planowane przedsięwzięcia. Podczas imprez proponowane są dzieciom różne zabawy dostosowane do ich potrzeb i możliwości. Najczęściej są to:

- zabawy ruchowe rozwijające motorykę małą i dużą; 
- zabawy taneczne, w których animator pokazuje dzieciom układy kroków/ czynności do piosenek, np. Chocolate (choco-choco), Boogi-woogi, Wyginam śmiało ciało, Kaczuchy, Jedzie pociag $z$ daleka itp.;

- zabawy z opowieścią, w których dzieci na określony znak wykonują pewien ruch bądź gest, np. jako śnieżynki obiegają dookoła inne dzieci.

$\mathrm{Z}$ uwagi na potrzebę rozładowania energii układane są zabawy na zasadzie zawodów międzygrupowych, np. przerzucanie śnieżek na boisko przeciwników, podawanie kartki między nogami itp. Dzieci bardzo chętnie biorą udział w wyścigach oraz zabawach z piłką, m.in. przenoszeniu na łyżeczce kuleczki ping-pongowej, podawaniu piłki w parach z określonej pozycji. Animatorzy zrzeszeni w Kole wykorzystują też często chustę KLANZY. Przy jej użyciu prowadzone są zabawy takie jak: mecz, kolory, rekin, Calineczka i wiele innych.
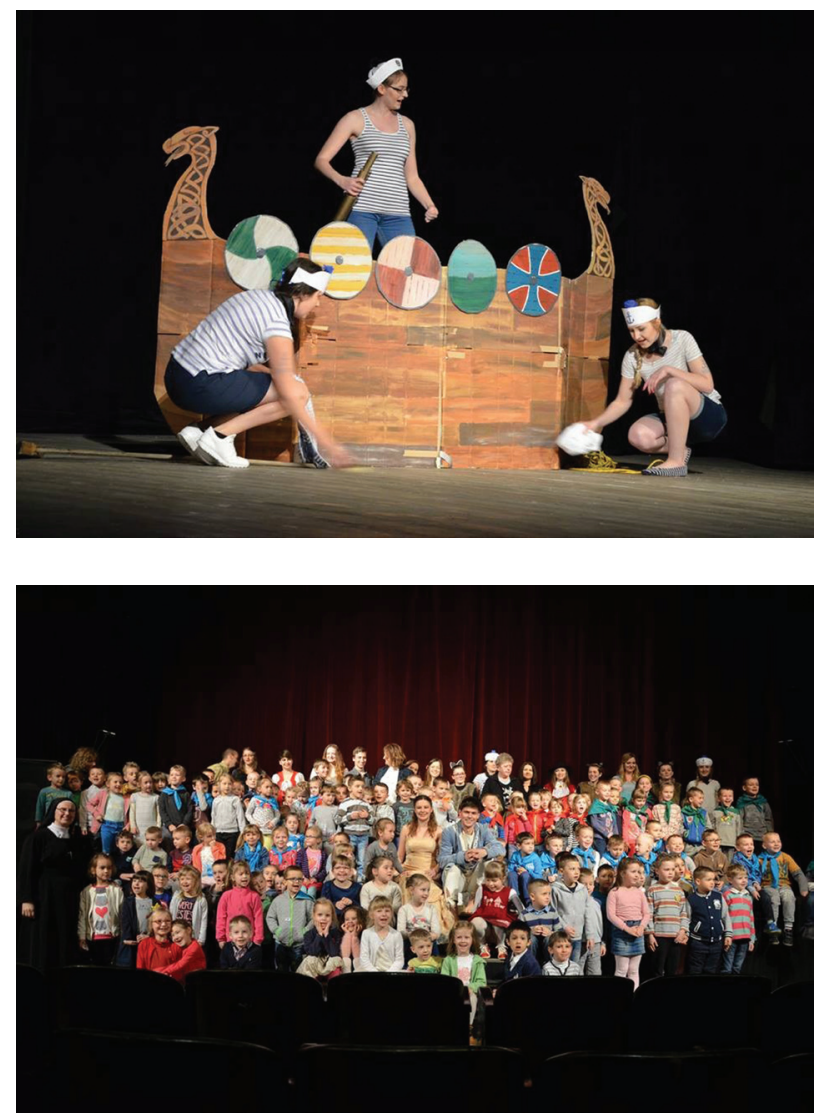

Zdjęcia 4 i 5. Studenci podczas przedstawienia dla dzieci Piękna i Bestia oraz wszyscy aktorzy z widzami

Źródło: materiały własne Koła. 
Elementem przygotowania z pedagogiki zabawy jest również pisanie projektów dotyczących pozyskiwania środków finansowych i organizowania różnych wydarzeń. Dzięki tym projektom Koło mogło zakupić sprzęt multimedialny (laptop, głośniki, kolumnę przenośną), jak również wyjechać do Norwegii, gdzie w polskiej szkole studenci prowadzili zajęcia z dziećmi oraz szkolenia dla rodziców i nauczycieli.

$\mathrm{Na}$ koniec należy jeszcze podkreślić, że choć praktyka czyni mistrza, to jednym $\mathrm{z}$ warunków, by tak się stało, jest pasja osób zaangażowanych w działanie. Współczesne badania dotyczące wypalenia zawodowego i jego wpływu na jakość pracy (Tucholska 2003; Kirenko, Zubrzycka-Maciąg 2011), a także tzw. neuronów lustrzanych (Bauer 2008, Vetulani 2010, Kalat 2011) wskazują, że postawa osób dorosłych warunkuje zachowania dzieci, również w zakresie zabawy. Nauczyciel czy rodzic uczestniczący w danym działaniu powinien działać z radością, może także z podekscytowaniem. Dlatego tak ważne jest poszukiwanie takich form i tematów, które będą bliskie nie tylko dzieciom, ale także opiekunom. Nie oznacza to, że mają oni zawsze z radością bawić się z dziećmi, ale powinni pamiętać, że zabawa jest konieczna do tego, by mogły się rozwijać, a jej skuteczność zależy również od postawy dorosłych (na ile ograniczają dziecko, na ile tworzą warunki, na ile cieszą ich zachowania dziecka, na ile uważają je za potrzebne). Warto zatem nie tylko znaleźć czas na zabawę z dzieckiem, ale również nie traktować go jako zmarnowany i bezproduktywny.

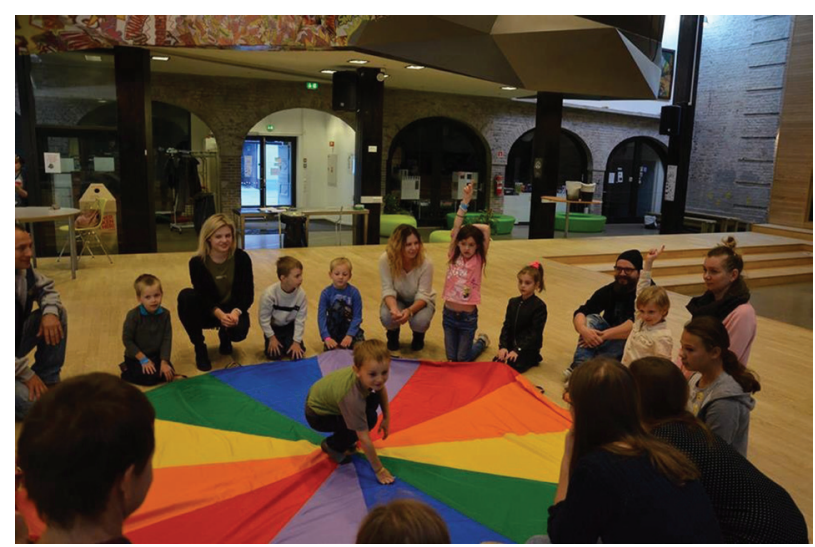

Zdjęcie 6. Wspólne zabawy z dziećmi i rodzicami w Szkole Polskiej we Fredrikstad w Norwegii

Źródło: materiały własne Koła.

Podsumowując, trzeba jeszcze zaznaczyć, że nie każda zabawa wspiera rozwój dziecka. Rozwijający się organizm nie potrzebuje bowiem zabaw typu: oglądanie telewizji, gra na komputerze czy komórce. Najnowsze badania potwierdzają, że im 
dłużej dziecko ma kontakt z mediami, tym częściej pojawiają się u niego otyłość, problemy ze wzrokiem, zaburzenia koncentracji, ubogie słownictwo, trudności w kontaktach społecznych czy wielozadaniowość (Chojak 2015, 2016). Na załączonych zdjęciach nie ma komputerów ani telefonów komórkowych nie dlatego, że są czymś złym, lecz dlatego, że organizm małego dziecka potrzebuje działań polisensorycznych. Tylko wtedy mogą ukształtować się takie połączenia neuronalne, które są niezbędne m.in. do efektywnej edukacji.

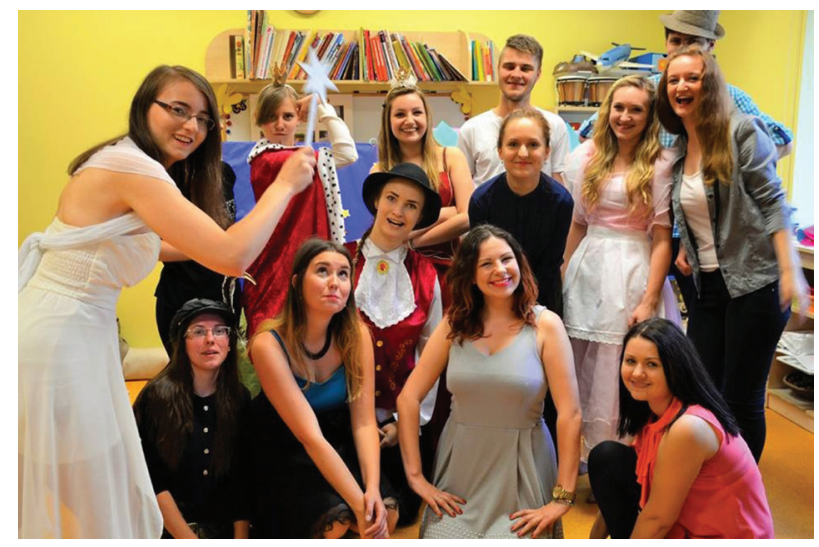

Zdjęcie 7. Przedstawienie dla dzieci z jednego z lubelskich przedszkoli (zdjęcie dobrze ilustruje pojęcie pasji)

Źródło: materiały własne Koła.

\section{LITERATURA}

Bauer J., 2008, Empatia. Co potrafia lustrzane neurony. Warszawa, Wydawnictwo Naukowe PWN.

Brzezińska A., 2005, Psychologiczne portrety człowieka. Gdańsk, GWP.

Brzezińska A.I. i in., 2011, O roli zabawy w przygotowaniu dziecka do dorosłego życia. „Wychowanie w Przedszkolu”, 10, 5-13.

Brzezińska A., Burtowy M., 1992, Psychopedagogiczne problemy edukacji przedszkolnej. Poznań, Wydawnictwo UAM.

Brzezińska A., Czub T., 1991, O zakłóceniach w ciagłości rozwoju dziecka. „Wychowanie w Przedszkolu", 7, 262-270.

Chojak M., 2016, Nadmierny kontakt z mediami jako przyczyna zaburzeń rozwoju poznawczego dzieci kończacych wychowanie przedszkolne - raport z badań. W: A. Kamińska. P. Oleśniewicz (red.), Edukacja jutra. Aspekty wychowania i kształcenia we współczesnej szkole. Sosnowiec, Oficyna Wydawnicza Humanitas. 
Chojak M., 2015, Rozwijanie kluczowych kompetencji u „dzieci sieci” w odniesieniu do najnowszych badań nad mózgiem. W: J. Uszyńska-Jarmoc, K. Nadachewicz (red.), Kompetencje kluczowe dzieci i młodzieży. Praktyka edukacyjna. Warszawa, Wydawnictwo Akademickie Żak.

Czub M., 2013, Nauka czy zabawa? „Wychowanie w Przedszkolu”, 5, 5-10.

Czub T., 1995, Proces bawienia się i jego właściwości terapeutyczne. W: A. Brzezińska i in. (red.), Dziecko w zabawie i świecie języka. Poznań, Wydawnictwo Zysk i Kas.

Erikson E.H., 1995, Zabawa i aktualność. W: A. Brzezińska i in. (red.), Dziecko w zabawie i świecie języka. Poznań, Wydawnictwo Zysk i S-ka.

Huizinga J., 1987, Homo ludens. Zabawa jako źródło kultury. Warszawa, Wydawnictwo Czytelnik.

Hurlock E., 1985, Rozwój dziecka. Warszawa, Wydawnictwo Naukowe PWN.

Kaczmarska D., Zamęcka N., 2013, Organizowanie czasu i przestrzeni kilkulatka. „Wychowanie w Przedszkolu”, 3, 42-47.

Kalat J.W., 2011, Biologiczne podstawy psychologii. Warszawa, Wydawnictwo Naukowe PWN.

Karbowniczek J., Kwaśniewska M., Surma B., 2013, Podstawy pedagogiki przedszkolnej z metodyką. Kraków, Wydawnictwo Akademia Ignatianum.

Kirenko J., Zubrzycka-Maciąg T., 2011, Współczesny nauczyciel: studium wypalenia zawodowego. Lublin, Wydawnictwo UMCS.

Krasa Z., 2009, Dzieciństwo służy do zabawy. „Bliżej Przedszkola”, 1, 68-69.

Kustosz S., 2013, Co rodzice o zabawie wiedzieć powinni. „Wychowanie w Przedszkolu”, 11.

Lipina S., 1981, Metodyka wychowania w przedszkolu. Warszawa, WSiP.

Lubomirska K., 2006, Zabawa i jej znaczenie dla rozwoju dziecka w pogladach Lwa

S. Wygotskiego. „Wychowanie w Przedszkolu”, 3, 4-7.

Maciejewska-Mroczek E., 2012, Mrówcza zabawa. Kraków, Towarzystwo Autorów i Wydawców Prac Naukowych Universitas.

Minczakiewicz E., 2013, Zabawy i zabawki niezwykłe. „Bliżej Przedszkola”, 1, 18-22.

Okoń W., 1987, Zabawa a rzeczywistość. Warszawa, WSiP.

Ożadowicz N., Rękosiewicz M., 2011, Aktywność zabawowa w wieku przedszkolnym. „Remedium”, 6, 4-5.

Truskolaska J., 2007, Osoba i zabawa. Lublin, Wydawnictwo KUL.

Tucholska S., 2003, Wypalenie zawodowe u nauczycieli: psychologiczna analiza zjawiska i jego osobowościowych uwarunkowań. Lublin, Wydawnictwo KUL.

Wenner M., 2009, Zabawa obowiązkowa. „Psychologia Dziś”, 1 (12), 32-37.

Winnicott D.W., 1995, Bawienie się. Rozważania teoretyczne. W: A. Brzezińska i in. (red.), Dziecko w zabawie i świecie języka. Poznań, Wydawnictwo Zysk i S-ka. 
Vetulani J., 2010, Mózg: fascynacje, problemy, tajemnice. Kraków, Wydawnictwo Homini.

\author{
FUN AS THE CONDITION OF THE PROPER DEVELOPMENT OF \\ THE CHILD AND THE PREPARATION OF STUDENTS TO THE \\ PROFESSION OF A TEACHER - AN EXAMPLE OF A PRACTICE
}

\begin{abstract}
It is widely known that fun has a huge impact on the development of a small human being, since it has accompanied it on the path of development as an overwhelming aspect of its life since its early childhood. It is not just a way to get to know the world as well as oneself, but it is also a way to learn new skills, express emotions, react to difficult events or just to relax. Numerous research results on developmental disorders of those, who have not experienced enough fun emphasize how important it is for a child to have fun and play. What is also important is that it is often the most effective way of communicating between a child and an adult. Therefore, it should be part of every course preparing teachers to work with children.
\end{abstract}

Keywords: child, play, development 